Volume 5 Nomor 2, Agustus 2020, halaman 172-182

\title{
MENINGKATKAN HASIL BELAJAR MATEMATIKA SISWA MENGGUNAKAN MODEL PEMBELAJARAN TEAMS GAMES TOURNAMENTS PADA MATERI TRIGONOMETRI
}

\section{IMPROVING STUDENT MATHEMATICS LEARNING RESULTS USING TEAMS GAMES TURNAMENTS LEARNING MODEL IN TRIGONOMETRY MATERIALS}

\author{
Lusi Siti Aisah $^{\mathbf{1}}$, Ine Wicanti ${ }^{2}$ \\ ${ }^{1}$ Universitas Wiralodra, J1.Ir.H.Djuanda KM. 3 Singaraja Indramayu \\ ${ }^{2}$ SMAN 1 Krangkeng, Jalan Raya Krangkeng No. 1, Indramayu \\ Email: lusi.sitiaisah@unwir.ac.id, ine wicanti@gmail.com
}

\begin{abstract}
ABSTRAK
Penilitian ini bertujuan untuk mengetahui peningkatan hasil belajar matematika siswa yang mendapatkan model pembelajaran Teams Games Tournament (TGT) pada materi trigonometri.Metode penelitian yang digunakan adalah metode kuasi eksperimen dengan desain non-equivalent pretest and postest control group design. Penelitian ini dilakukan di SMA Negeri 1 Krangkeng. Pengambilan sampel dilakukan berdasarkan pertimbangan (sampling purposif).Sampel dalam penelitian ini adalah sebanyak 2 kelas, yaitu X-5 MIPA sebanyak 33 siswa sebagai kelas eksperimen dan X-6 MIPA yang berjumlah 33 siswa sebagai kelas kontrol. Dalam pembelajarannya, kelas eksperimen melakukan pembelajaran kooperatif tipe Teams Games Tournaments (TGT) sedangkan kelas kontrol melakukan pembelajaran biasa (tidak menggunakan pembelajaran kooperatif tipe TGT). Perbedaan peningkatan rerata $\mathrm{N}$-gain dianalisis menggunakan uji independent sample t test. Hasil analisis statistik menunjukkan bahwa pembelajaran kooperatif tipe Teams Games Tournaments (TGT) dapat meningkatkan hasil belajar matematika siswa pada materi trigonometri.
\end{abstract}

Kata Kunci : Teams Games Turnaments, Hasil Belajar, Trigonometri

\section{ABSTRACT}

The purpose of this study is to determine improvement mathematics learning outcomes of students who get the Teams Games Tournament (TGT) learning model on trigonometry material. The research method is quasi-experiment with a non-equivalent pretest and posttest control group design. This research was held at SMA Negeri 1 Krangkeng. Sampling was carried out based on consideration (purposive sampling). The samples in this study were 2 classes, namely X-5 MIPA as many as 33 students as the experiment class and X-6 MIPA which totaled 33 students as the control class. In learning, the experimental class got cooperative learning type Teams Games Tournaments (TGT) while the control class got regular learning (not using TGT type cooperative learning). The difference of $\mathrm{N}$-gain increase was analyzed using the independent sample $\mathrm{t}$ test. The results of statistical analysis show that cooperative learning type Teams Games Tournaments (TGT) can improve students' mathematics learning outcomes on trigonometric material.

Keyword(s): Teams Games Turnaments, Learning Outcomes, Trigonometry 
How to Cite: Aisah, L.S., \& Wicanti, I. (2020). Meningkatkan Hasil Belajar Matematika Siswa Menggunakan Model Pembelajaran Teams Games Tournaments (TGT) Pada Materi Trigonometri. Mathline: Jurnal Matematika dan Pendidikan Matematika, Vol. 5 No. 2, 172-182.

DOI: https://doi.org/10.31943/mathline.v5i2.158

\section{PENDAHULUAN}

Dalam proses pembelajaran matematika penguasaan konsep matematika sangat penting bagi siswa. Jika siswa menguasai konsep dengan baik, maka hasil belajar matematikanya pun akan baik. Kenyataan yang ada, penguasaan materi matematika pada siswa di tingkat pendidikan dasar dan menengah masih rendah. Hal ini dapat dilihat salah satunya dari hasil survei tiga tahunan Program for International Student Assessment (PISA) tahun 2012 oleh Organization for Economic Cooperation and Development (OECD) Indonesia berada di urutan ke 63 dari 64 negara dalam bidang matematika. Selanjutnya Hasil laporan Badan Penelitian dan Pengembangan bahwa hasil evaluasi TIMSS (Trends in Student Achievement in Mathematics and Science) tahun 2011 prestasi belajar matematika kelas VII di Indonesia berada di posisi 5 besar dari bawah yaitu peringkat 36 dari 40 negara dengan nilai 386 (Linggar Galih Maharani \& Budi Murtiyasa, 2016:2).

Menurut Teguh Prasojo (2016: 91), hasil belajar matematika merupakan hasil akhir dari suatu proses belajar matematika sebagai perwujudan usaha yang telah dilakukan selama proses itu berlangsung. Sementara itu, pencapaian hasil belajar lebih sering dikaitkan dengan nilai perolehan siswa setelah proses belajar mengajar dan evaluasi yang diberikan. Sedangkan, menurut Syaiful Bahri Djamarah (Norkhamid, 2017: 21), menyatakan hasil belajar atau prestasi belajar adalah hasil dari suatu kegiatan yang telah dikerjakan, atau diciptakan secara individu atau kelompok. Berdasarkan ungkapan tersebut dapat ditarik kesimpulan bahwa tidak akan ada hasil belajar apabila tidak ada kegiatan pembelajaran.

Rendahnya hasil belajar matematika siswa dipengaruhi oleh berbagai faktor, di antaranya yaitu faktor kurangnya minat siswa dalam belajar matematika (Ardilla dan Hartanto: 2017). Keberminatan siswa tentunya berpengaruh terhadap proses dan hasil pembelajaran Lebih lanjut, penelitian yang dilakukan oleh Ardilla dan Hartanto (2017) pada siswa MTS mengungkapkan bahwa selama proses pembelajaran berlangsung siswa kurang terlibat dan tertarik di dalam pembelajaran. Siswa kurang merespon dan memperhatikan saat guru menjelaskan. Akibatnya hasil belajar matematika pun cenderung rendah. 
Guru memiliki peranan penting dalam melaksanakan pembelajaran yang menarik untuk mencapai hasil belajar yang maksimal (Hartanto, 2016). Sejalan dengan itu Damayanti dan Apriyanto (2017) menyatakan bahwa dalam upaya meningkatkan hasil belajar siswa, guru tidak harus terpaku dengan satu model pembelajaran tetapi guru sebaiknya menggunakan model pembelajaran yang bervariasi. Berdasarkan hal tersebut, guru harus bisa memilih dan memilah metode pembelajaran mana yang tepat dan sesuai untuk digunakan dalam proses pembelajaran.

Selama ini model pembelajaran yang digunakan masih konvensional, pada umumnya guru hanya menjelaskan materi secara teoretis, berdasarkan hasil penelitian di SMA Tamansiswa (TAMSIS) Padang, kebanyakan proses pembelajaran matematika yang terjadi masih bersifat satu arah (Fauziah, 2015: 1). Pembelajaran konvensional dengan komunikasi satu arah mengabaikan sifat sosial dari belajar matematika, juga mengganggu perkembangan matematika siswa. Untuk itu diperlukan model pembelajaran secara berkelompok, sehingga siswa mampu berkomunikasi bersama temannya untuk membangun pengetahuan dari aktifitas belajar kelompok.

Salah satu model pembelajaran yang diharapkan dapat meningkatkan hasil belajar matematika siswa adalah model pembelajaran kooperatif tipe Teams Games Tournament (TGT). Menurut Agus Suprijono (2009: 54) mengemukakan bahwa pembelajaran kooperatif adalah konsep yang lebih luas meliputi semua jenis kerja kelompok termasuk bentuk-bentuk yang lebih dipimpin oleh guru atau diarahkan oleh guru. Auyawati dan Sujadi (2016) dan Susanti et al. (2020) mengungkapkan bahwa model pembelajaran kooperatif tipe TGT memiliki unsur permainan dan penghargaan dalam pembelajaran diharapkan siswa lebih aktif dan tidak menganggap matematika sebagai pelajaran yang sulit untuk dipelajari. Pembelajaran matematika dengan model kooperatif tipe Teams Games Tournaments (TGT) menurut Ramadiana, dkk (2019) dapat mengembangkan kreativitas siswa. Sejalan dengan itu, Oktavia (2015) juga menemukan bahwa kreativitas dapat meningkatkan pemahaman konsep matematika. Jika kreativitas siswa baik, siswa akan berusaha mencoba beragam cara untuk menyelesaikan permasalahan matematika. Kemudian penelitian yang dilakukan oleh Saptayanti dkk (2016) mengungkapkan bahwa setelah menerapkan model pembelajaran Teams Games Tournament, siswa menjadi lebih giat belajar. Selanjutnya dalam penelitian Setiawan (2017) didapat fakta bahwa selama proses pembelajaran dengan Teams model Games Tournament, siswa berperan aktif selama pembelajaran berlangsung tanpa bergantung sepenuhnya pada guru. Siswa dapat bertanggung jawab, saling memotivasi dan bekerja sama dalam memecahkan masalah atau tugas dari guru. Hasil 
penelitian yang dilakukan Chairhany (2020) juga mengungkapkan bahwa penerapan model pembelajaran koperatif $T G T$ dapat meningkatkan motivasi dan hasil belajar matematika siswa SMK. Selanjutnya, penelitian yang dilakukan oleh Damayanti dan Apriyanto (2017) mengungkapkan bahwa Pembelajaran kooperatif tipe Teams Game Tournament (TGT) membuat siswa senang dan nyaman dalam proses pembelajaran sehingga siswa tidak lagi menganggap matematika sebagai pelajaran yang "menakutkan", hal tersebut menyebabkan hasil pembelajaran siswa pun menjadi lebih baik.

Berdasarkan latar belakang yang diuraikan di atas maka peneliti telah melakukan penelitian "Meningkatkan Hasil Belajar Matematika Siswa Menggunakan Model Pembelajaran Teams Games Tournaments (TGT) pada materi Trigonometri". Penelitian ini bertujuan untuk mengkaji Apakah model pembelajaran Teams Games Tournament (TGT) dapat meningkatkan hasil belajar matematika pada pokok bahasan trigonometri.

\section{METODE PENELITIAN}

Metode penelitian yang digunakan adalah metode kuasi eksperimen. Menurut Cresswell (2010), untuk rancangan kuasi eksperimen dengan desain non-equivalent pretest and postest control group design, kelas eksperimen dan kelas kontrol diseleksi tanpa prosedur acak. Pada penelitian ini subjek tidak dikelompokkan secara acak, tetapi keadaan subjek diterima sebagaimana adanya (Ruseffendi, 2010).

Adapun desain penelitian ini adalah sebagai berikut::

\begin{tabular}{llll} 
Kelas Eksperimen & $: \mathrm{O}$ & $\mathrm{X}$ & $\mathrm{O}$ \\
\hline Kelas Kontrol & $: \mathrm{O}$ & & $\mathrm{O}$
\end{tabular}

\section{Keterangan:}

$\mathrm{O} \quad$ : pretes dan postes hasil belaja matematika siswa

X : pembelajaran matematika dengan model Teams Games Tournament (TGT) : subjek diseleksi tanpa prosedur penempatan acak

Penelitian ini dilakukan di SMA Negeri 1 Krangkeng. Sampel dalam penelitian ini adalah sebanyak 2 kelas, yaitu X-5 MIPA sebanyak 33 siswa sebagai kelas eksperimen dan X-6 MIPA yang berjumlah 33 siswa sebagai kelas kontrol. Pengambilan sampel dilakukan berdasarkan pertimbangan (sampling purposif) yaitu pertimbangan guru mata pelajaran matematika. Pertimbangan ini berdasarkan atas kemampuan siswa yang relatif setara dilihat dari nilai rata-rata kedua kelas yang rata-ratanya tidak jauh berbeda. Selain itu, pertimbangan ini berdasarkan atas waktu yang memungkinkan kedua kelas yang diambil tidak ada irisan waktu karena diampu oleh satu guru matematika. 
Dalam pembelajarannya, kelas eksperimen melakukan pembelajaran kooperatif tipe Teams Games Tournaments (TGT) sedangkan kelas kontrol melakukan pembelajaran biasa (tidak menggunakan pembelajaran kooperatif tipe TGT). Instrumen yang digunakan dalam penelitian ini adalah tes uraian yang bertujuan untuk mengukur peningkatan hasil belajar matematika siswa pada materi trigonometri. Tes uraian ini diberikan dua kali kepada siswa saat sebelum pembelajaran dan setelah pembelajaran

Perbedaan hasil belajar antara keadaan awal dengan keadaan akhir diasumsikan sebagai efek dari perlakuan yang diberikan. Menurut Meltzer (2002) Learning gain is assessed through pre- and post-testing. Jadi Gain dalam pembelajaran dapat dihitung dari selisih antara skor pretest dan posttest. Sedangkan N-Gain adalah gain yang telah dinormalisasi. N-Gain digunakan untuk menghindari adanya bias penelitian yang disebabkan oleh perbedaan gain akibat skor pretest yang berbeda antara kelas eksperimen dan kontrol.

Gain ternormalisasi (normalized gain), yang dikembangkan oleh Hake (1999) yaitu:

$$
\begin{gathered}
\text { Gain ternormalisasi }(g)=\frac{\% \mathrm{~S}_{\mathrm{f}}-\% \mathrm{~S}_{\mathrm{i}}}{100-\% \mathrm{~S}_{\mathrm{i}}} \quad \text { (Hake, 1999) } \\
\text { dengan } \mathrm{Sf}=\text { Skor post-test } \\
\mathrm{Si}=\text { Skor pre-test }
\end{gathered}
$$

Hasil perhitungan gain ternormalisasi (N-Gain) tersebut kemudian diinterpretasikan dengan menggunakan kriteria dari Hake (1999) sebagai berikut:

\section{Tabel 1 Kriteria Gain Ternormalisasi}

\begin{tabular}{cc}
\hline Besarnya $\mathbf{g}$ & Interpretasi \\
\hline Indeks gain $\geq \mathbf{0 , 7}$ & Tinggi \\
$\mathbf{0 , 3} \leq \mathbf{g}<\mathbf{0 , 7}$ & Sedang \\
$\mathbf{g}<\mathbf{0 , 3}$ & Rendah \\
\hline
\end{tabular}

\section{HASIL DAN PEMBAHASAN}

Penelitian ini dilakukan di SMA Negeri 1 Krangkeng pada tanggal 03 Februari 2020 - 17 Februari 2020. Di awal pertemuan, kedua kelas sampel diberikan pretes. Setelah itu kedua kelas diberi perlakuan berupa pembelajaran kooperatif tipe TGT untuk kelas eksperimen, dan kelas kontrol diberikan pembelajaran biasa (tidak menggunakan pembelajaran kooperatif tipe TGT), selanjutnya diakhiri dengan postes. Hasil penelitian dan pembahasan lebih lanjut akan diuraikan sebagai berikut. 
Tabel 2 Deskripsi Hasil Belajar Matematika Siswa

\begin{tabular}{lcccc}
\hline Kelas & $\overline{\boldsymbol{x}}$ Pretes & $\overline{\boldsymbol{x}}$ Postes & $\overline{\boldsymbol{x}}$ Gain & $\overline{\boldsymbol{x}}$ N-Gain \\
\hline Eksperimen & 40,31 & 81,69 & 41,38 & 0,72 \\
Kontrol & 41,43 & 75,06 & 33,63 & 0,57 \\
& \multicolumn{3}{c}{ Skor Maksimum Ideal $=100$} \\
\hline
\end{tabular}

Berdasarkan Tabel 1 dapat kita lihat secara keseluruhan, rata-rata skor pretes kelas eksperimen sebesar 40,31 sedangkan rata-rata pretes kelas kontrol 41,43 dari total skor maksimum ideal 100. Secara keseluruhan, rata-rata pretes kelas kontrol lebih tinggi 1,12 dari kelas eksperimen. Selanjutnya, Rata-rata Skor postes kelas eksperimen adalah sebesar 81,69 sedangkan rata-rata postes kelas kontrol 75,06. Dari data tersebut kita dapatkan ratarata postes kelas eksperimen lebih tinggi 6,63 dari kelas kontrol.

Untuk melihat peningkatannya, bisa kita lihat dari Gain yang didapat. Gain adalah selisih antara skor pretest dan posttest. Untuk kelas eksperimen, rata-rata Gain adalah sebesar 41,38 sedangkan kelas kontrol 33,63. Terdapat selisih antara keduanya, rata-rata Gain kelas eksperimen lebih besar 7,75 dari kelas kontrol. Selanjutnya untuk menganalisis besarnya peningkatan hasil belajar matematika siswa yang diperoleh dari skor pretes dan postes akan digunakan data nilai rata-rata Gain ternormalisasi (N-Gain). Rata-rata N-Gain kelas eksperimen adalah 0,72 sedangkan kelas kontrol 0,57. Data tersebut menunjukkan bahwa peningkatan hasil belajar matematika siswa kelas eksperimen lebih tinggi 0,15 dari kelas kontrol, dengan kualitas peningkatan pada kelas eksperimen berada pada level tinggi sedangkan kelas kontrol berada pada level sedang.

Selanjutnya, perbandingan rata-rata pretes, postes, gain, dan N-Gain hasil belajar matematika siswa pada materi trigonometri disajikan pada Gambar 1 berikut:

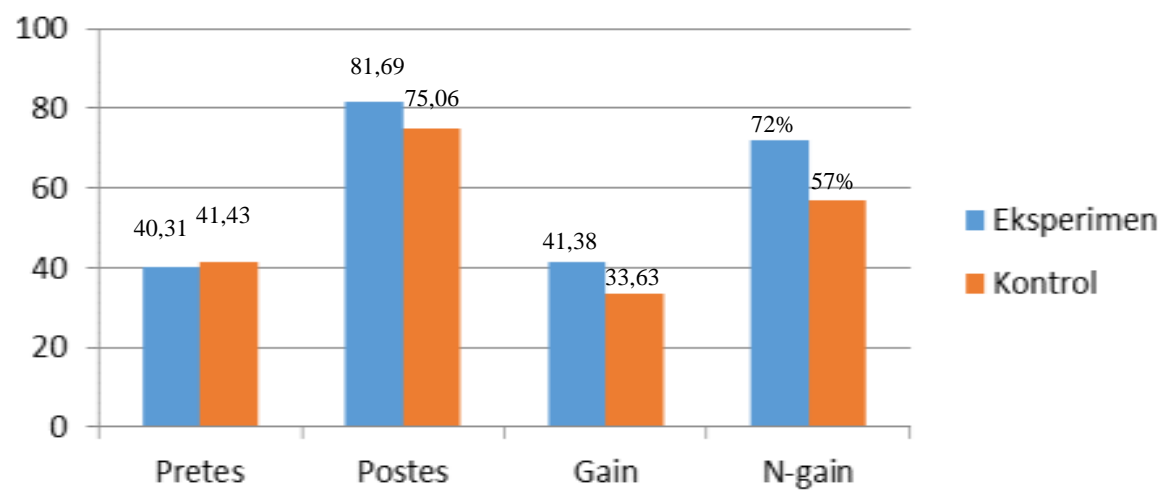

Gambar 1 Perbandingan Rata-rata Pretest, Posttest, Gain, dan N-gain Hasil Belajar siswa pada materi Trigonometri 
Pada gambar 1 terlihat bahwa rata-rata nilai pretes kelas kontrol lebih unggul dari kelas eksperimen, sedangkan rata-rata nilai postes, gain dan $\mathrm{N}-$ Gain lebih unggul kelas eksperimen dibanding kelas kontrol. Dari tabel 2 dan gambar 1 dapat disimpulkan hasil belajar matematika siswa pada materi trigonometri pada kelas eksperimen yang pembelajarannya menggunakan metode pembelajaran kooperatif tipe TGT lebih tinggi nilainya jika dibandingkan dengan kelas kontrol.

Untuk mengetahui lebih lanjut apakah perbedaan tersebut signifikan, perlu dilakukan uji perbedaan rata-rata secara statistik. Sebelumnya, akan dilakukan uji normalitas dan homogenitas terlebih dahulu untuk menentukan uji statistik yang digunakan apakah parametrik atau nonparametrik. Perhitungan statistik pada penelitian ini dibantu dengan bantuan software SPSS 20.0 for Windows.

\section{Uji Normalitas}

Uji normalitas dihitung pada taraf signifikansi $\alpha=0,05$. Kriteria pengujian normalitas yaitu, jika nilai probabilitas sig. ( $p$-value $) \geq \alpha=0,05$, maka $\mathrm{H}_{0}$ diterima. Tolak $\mathrm{H}_{0}$ jika sig. ( $p$-value $)<\alpha=0,05$. Hasil uji normalitas peningkatan hasil belajar matematika siswa dapat dilihat pada tabel berikut.

Tabel 3 Hasil Uji Nomalitas Peningkatan Hasil Belajar Matematika Siswa

\begin{tabular}{lcccccc}
\hline & \multicolumn{3}{c}{ Shapiro-Wilk } & & Ket & Kesimpulan \\
\cline { 2 - 4 } Eksperimen & 0,964 & 33 & 0,343 & & Terima $\mathrm{H}_{0}$ & $\begin{array}{c}\text { Berdistribusi } \\
\text { Normal } \\
\text { Kontrol }\end{array}$ \\
\cline { 2 - 3 } & 0,950 & 33 & 0,132 & & Terima $\mathrm{H}_{0}$ & $\begin{array}{c}\text { Berdistribusi } \\
\text { Normal }\end{array}$ \\
\hline
\end{tabular}

Dari tabel 3 tampak bahwa nilai sig. kedua kelas $(0,343$ dan 0,132$)$ lebih dari taraf signfikansi $\alpha=0,05$ yang ditetapkan, artinya peningkatan hasil belajar matematika siswa di kedua kelas berdistribusi normal pada taraf signifikansi $\alpha=0,05$.

\section{Uji Homogenitas}

Tabel 4 Hasil Uji Homogenitas Hasil Belajar Matematika Siswa

\begin{tabular}{ccccccc}
\hline Aspek & $\begin{array}{c}\text { Levene } \\
\text { Statistic }\end{array}$ & df1 & df2 & Sig. & Ket. & Kesimpulan \\
\hline $\begin{array}{c}\text { Gain Based } \\
\text { on Mean }\end{array}$ & 0,520 & 1 & 64 & 0,473 & Terima $\mathrm{H}_{0}$ & Homogen \\
\hline
\end{tabular}


Berdasarkan tabel di atas, nilai Sig. peningkatan hasil belajar matematika kelompok sampel memiliki nilai lebih dari taraf signifikansi yang dipilih, artinya data peningkatan pada kedua kelompok tersebut bervariansi homogen.

\section{Uji Perbedaan Rata-rata Peningkatan Hasil Belajar Matematika siswa}

Berdasarkan hasil uji normalitas dan homogenitas, diperoleh bahwa data hasil belajar matematika siswa pada kelas eksperimen dan kelas kontrol berdistribusi normal dan homogen. Selanjutnya, untuk melihat perbedaan peningkatan akan dilakukan pengolahan data lebih lanjut dengan menggunakan uji parametrik, uji independent sample t test. Perhitungannya menggunakan bantuan software SPSS 20.0 for Windows, dengan taraf signifikansi $\alpha=0,05$. Kriteria pengujian adalah terima $\mathrm{H}_{0}$ jika Sig. (2-tailed) $\geq$ taraf signifikansi $\alpha=0,05$ dan tolak $\mathrm{H}_{0}$ jika Sig. (2-tailed) $<$ taraf signifikansi $\alpha=0,05$; Rangkuman hasil perhitungan secara ringkas ditujukan pada tabel 5 berikut ini:

Tabel 5 Uji Perbedaan Rata-Rata Peningkatan Hasil Belajar Matematika Siswa

\begin{tabular}{|c|c|c|c|c|c|}
\hline & \multicolumn{3}{|c|}{$\begin{array}{c}\text { t-test for Equality of } \\
\text { Means } \\
\end{array}$} & \multirow[t]{2}{*}{ Ket } & \multirow[t]{2}{*}{ Kesimpulan } \\
\hline & $\mathbf{t}$ & df & $\begin{array}{c}\text { Sig. } \\
(2-\text { tailed })\end{array}$ & & \\
\hline $\begin{array}{l}N \text {-Gain Equal variances } \\
\text { assumed }\end{array}$ & 3,819 & 64 & 0,000 & Tolak $\mathrm{H}_{0}$ & $\begin{array}{l}\text { Terdapat } \\
\text { Perbedaan }\end{array}$ \\
\hline
\end{tabular}

Tabel di atas diperoleh hasil Sig. (2-tailed $)=0,000$, yang menunjukkan nilai lebih kecil dari taraf signfikansi $\alpha=0,05$ yang ditetapkan. Akibatnya $\mathrm{H}_{0}$ ditolak. Ini berarti terdapat perbedaan rata-rata peningkatan hasil belajar matematika siswa antara kelas eksperimen dan kelas kontrol. Dengan kata lain, dapat disimpulkan bahwa terdapat perbedaan secara signifikan dalam peningkatan hasil belajar matematika siswa yang memperoleh pembelajan kooperatif tipe Teams Games Tournaments (TGT) dengan siswa yang memperoleh pembelajaran biasa (tidak menggunakan pembelajaran kooperatif tipe TGT).

Selanjutnya dari hasil lembar observasi saat penelitian berlangsung, mengungkapkan bahwa peneliti telah melaksanakan pembelajaran sesuai dengan rencana pelaksanaan pembelajaran yang dirancang dan pembelajaran berlangsung dengan baik. Respon siswa saat mengikuti pembelajaran matematika menggunakan model pembelajaran kooperatif tipe Teams Games Tournaments (TGT) cukup beragam. Diawal pembelajaran dibutuhkan waktu untuk siswa beradaptasi dalam memahami aturan pembelajaran menggunakan model kooperatif tipe Teams Games Tournaments (TGT). Beberapa siswa 
yang belum siap belajar perlu diberi motivasi dahulu agar siap untuk melaksanakan pembelajaran. Pada pembelajaran kedua dan seterusnya terlihat ada peningkatan antusias siswa karena mulai banyak siswa yang semangat dan tertarik dalam mengikuti proses pembelajaran menggunakan metode pembelajaran Teams Games Tournaments (TGT).

Berdasarkan hasil uji statistik didapatkan kesimpulan bahwa terdapat perbedaan secara signifikan dalam peningkatan hasil belajar matematika siswa yang memperoleh pembelajaran kooperatif tipe Teams Games Tournaments (TGT) dengan siswa yang memperoleh pembelajaran biasa (tidak menggunakan pembelajaran kooperatif tipe TGT). Artinya pembelajaran matematika dengan model kooperatif tipe Teams Games Tournaments (TGT) terbukti mampu meningkatkan hasil belajar siswa. Penelitian ini sejalan dengan penelitian yang dilakukan oleh Saptayanti dkk (2016) yang mengungkapkan bahwa penerapan model pembelajaran Teams Games Tournaments (TGT) berpengaruh secara signifikan terhadap hasil belajar Matematika siswa. Kemudian Penelitian yang dilakukan oleh Ramadiana dkk (2019) juga mengungkapkan bahwa "the TGT type learning model has a significant influence on student's creativity and comprehension of concepts in mathematics learning." Artinya Pembelajaran dengan model Teams Games Tournaments (TGT) memiliki pengaruh yang signifikan terhadap kreativitas dan pemahaman konsep Matematika siswa. Selanjutnya hasil penelitian yang dilakukan Annurwanda (2018) menunjukkan bahwa TGT berpengaruh positif terhadap self-efficacy siswa dalam belajar matematika. Penampilan kelompok yang memenangkan permainan membuat siswa semakin percaya diri. Selain itu, para siswa yang tergabung dalam tim pemenang juga menunjukkan kinerja individu yang lebih baik dalam menyelesaikan pekerjaan individualnya. Peningkatan tersebut karena TGT memiliki beberapa fitur positif seperti permainan kooperatif dan permainan kompetitif interpersonal.

\section{KESIMPULAN}

Pembelajaran matematika dengan model kooperatif tipe Teams Games Tournaments (TGT) terbukti mampu meningkatkan hasil belajar siswa pada materi trigonometri. Hal ini dapat terlihat dari rerata hasil postes dan N-Gain kelas eksperimen lebih baik dari kelas kontrol. Selanjutnya dari uji statistik juga mengungkapkan bahwa rerata nilai $\mathrm{N}$-Gain kelas eksperimen lebih baik secara signifikan dari kelas kontrol sehingga pembelajaran matematika menggunakan model kooperatif tipe Teams Games Tournaments (TGT) dapat dijadikan salah satu alternatif model pembelajaran yang dapat 
diterapkan guru untuk meningkatkan hasil belajar matematika khususnya pada materi trigonometri.

\section{UCAPAN TERIMAKASIH}

Penulis mengucapkan terimakasih kepada Rektor Universitas wiraalodra yang telah memberikan hibah penelitian kepada tim kami. Terima kasih kepada Kepala SMAN 1 Krangkeng yang telah bekerjasama dengan kami. Terima kasih kepada Nurfaidah selaku mahasiswa yang membantu peenelitian ini serta semua pihak yang telah berperan dalam pelaksanaan penelitian ini, sehingga penelitian ini dapat terlaksana dengan baik.

\section{DAFTAR PUSTAKA}

Agus Suprijono. 2009. Cooperative Learning. Teori dan Aplikasi PAIKEM. Yogyakarta : Pustaka Pelajar

Annurwanda, P. 2018. The Effect of Teams Games Tournament on Mathematics SelfEfficacy in Junior High Schools. SHS Web of Conferences 42.

Ardilla, A., Hartanto, S. 2017. Faktor Yang Mempengaruhi Rendahnya Hasil Belajar Matematika Siswa Mts Iskandar Muda Batam. Jurnal Pythagoras, Vol 6 No.2: Hal $175-186$.

Chairhany,S. 2020. Meningkatkan Motivasi dan Hasil Belajar Matematika melalui Model Pembelajaran Koperatif Teams-Games-Tournament Siswa Kelas Xi Akuntansi Smk Negeri 1 Tembilahan. Jurnal Pendidikan Asatiza Vol 1, No3. Hal 310-316

Creswell, J. W. 2010. Research Design, Pendekatan Kualitatif, Kuantitatif, dan Mixed. Edisi Ketiga. Yogyakarta: Pustaka Pelajar.

Damayanti, S., dan Apriyanto,M.T. 2017. Pengaruh Model Pembelajaran Kooperatif Tipe Tgt (Teams Games Tournament) terhadap Hasil Belajar Matematika. JKPM. Vol. 02, No. 02. Hal 235-244.

Fauziah. 2015. Meningkatkan Hasil Belajar Matematika Siswa Kelas XI IPS SMA Tamansiswa Padang dengan Penggunaan Pendekatan Kontekstual Berbasis Tugas yang Menantang (Challenging Task). Lemma, vol. 1, no. 2, hal 1-9

Hake, R.R. 1999. Analyzing Change / Gain Scores. http://www.physics.indiana.edu/ sdi/ AnalyzingChange-Gain.pdf

Hartanto, S. 2016. Pengaruh Penerapan Model Pembelajaran Talking Stick Terhadap Hasil Belajar Matematika Siswa Kelas Viii Smp Negeri 11 Batam. Jurnal Phythagoras Hal. 12-19.

Linggar Galih Maharani dan Budi Murtiyasa. 2016. Kemampuan Pemecahan Masalah Matematika Aljabar Berbasis Timss Pada Siswa SMP Kelas VIII. Prosiding Seminar Nasional Pendidikan Matematika Universitas Muhammadiyah Surakarta.

Meltzer, D. E. 2002. The relationship between mathematics preparation and Conceptual learning gains in physics: A possible "hidden variable" in diagnostic pretest scores. Journal American Association of Physics Teachers, 70(12):1259-1268.

Norkhamid. 2017. Peningkatan Hasil Belajar Matematika Materi Limit Fungsi melalui Model Course Review Horray Bagi Peserta Didik XI IPA 4 SMAN 1 Mayong. Jurnal Aksioma, vol. 8, no. 2, hal 19-32 
Oktavia, I. 2015. Pengaruh Model Pembelajaran Kooperatif dan Kreativitas Belajar Siswa terhadap Pemahaman Konsep Matematika. Jurnal Kajian Pendidikan Matematika, Vol 1 No.1,Hal 16-30.

Ramadiana,A., In'am, A., Kusumawardana, A.S. 2019. The Effect of Cooperative Learning Type Teams Games Tournament (TGT) on Creativity and Comprehension the Student's Concept in Mathematics Learning. Mathematics Education Journals Vol 3 No. 1 Hal 17-24

Ruseffendi, E.T. 2010. Dasar-Dasar Penelitian Pendidikan dan Bidang Non-Eksakta lainnya. Bandung: Tarsito.

Saptayanti, G. A. K. E., Wibawa, I M. C., \& Pudjawan, K. 2016. Pengaruh Model Pembelajaran Kooperatif Tipe TGT (Teams Games Tournament) terhadap Hasil Belajar Matematika. E-Journal MIMBAR PGSD, Volume 4 Nomor 1, (hlm. 1-11).

Septiawan, I M. A. E., Rati, N. W., \& Murda, I. N. 2017. Pengaruh Model Pembelajaran Kooperatif Tipe TGT Berbantuan Media Audio Visual terhadap Hasil Belajar IPA. E-Journal MIMBAR PGSD, Volume 5, Nomor 2, (hlm. 1-11).

Susanti, E., Nandang, N., \& Puri, I. D. (2020). Penggunaan Model Pembelajaran Teams Games Tournament Untuk Meningkatkan Keaktifan Dan Hasil Belajar Siswa Pada Materi Aplikasi Barisan. Mathline: Jurnal Matematika Dan Pendidikan Matematika, 5(1), 37-46.

Teguh Prasojo. 2016. Peningkatan Aktivitas dan Hasil Belajar Matematika dengan Metode Tutor Sebaya pada Siswa Kelas X IPA 7 Materi Trigonometri SMA Negeri 1 Kudus. Jurnal Matematika Kretif-Inovatif, vol. 7, no. 1, hal 91-98. 